\title{
Public Works in the Spanish Empire: A Bridging Perspective
}

\author{
MANUEL LUCENA-GIR A L DO \\ Spanish National Research Council, Centro de Ciencias Humanas y Sociales - \\ Consejo Superior de Investigaciones Científicas, C/Albasanz, 26-28, Madrid \\ 28037, Spain. Email: manuel.lucena.giraldo@cchs.csic.es
}

Public works began, at least in the Spanish Empire, after the failure of Christopher Columbus's governance in the Antilles. The foundation of cities in the Americas was a colonization strategy. Urban republics formed a network to support the kingdoms of the Indies for more than three centuries. Far beyond traditional and nationalistic explanations, it was precisely the ability to establish bridges - social, as well as material - that explains the resilience and durability of this network until 1825.

\section{Empires}

One of the biggest problems of global history is 'how did pre-industrial empires function?' In their technological weakness, how did they promote mobility, harness loyalty, galvanize support, procure service, collect tribute or tax, disarm resistance, forge workable institutions of government, and enlist obedience? How did these huge, ill- articulated structures survive in competition with one another, and in defiance of new-born nation-states, and communal or elite-driven self-determination? How in some cases did they endure and even grow against the odds? Without collaborators empire was - and probably, to a lesser extent, still is - impossible. But how were partners made or found, collaborations negotiated and secured?

At the end of the eighteenth century, revolution and industrial capitalism appeared a sign of the times. Although a new British Empire was taking shape in India, the so-called First Empire, that of the Early Modern Caribbean and the thirteen North American colonies, collapsed by the 1780s. France's effort in North America vanished as early as 1763. The French Revolutionary and Napoleonic Wars inflicted an instant end on what France had retained in Saint-Domingue, causing enduring problems and in due course leading to the end of the Spanish and Portuguese Latin American empires (Paquette et al. 2018, 175-182).

As for the 'Republican Empire', the prospects were by no means universally pleasing. After 1823 and the Monroe doctrine, US republicanism saw itself as immune to 
the loss of political virtues attributed to old-fashioned European empires. The self-indulgence of the 'consummation of empire' was not considered, and thence an inevitable decline and fall, such as the Romans and their modern successors had suffered, was not on the lists.

Yet major questions remain unexplained. Why did Early Modern European empires last for so long? During the last decades, Global History, although sometimes accused of merely restyling old imperialist and Western-centred models, has offered new ways of research. If, as just one possible definition between many others, civilization is a process of the modification of nature for human purposes, empire takes environmental adaptation a stage further - re-fashioning landscape for political ends, building infrastructure to link disparate communities into a single polity, or at least into a bundle, with common ties of belonging and allegiance. For Early Modern European imperialists, the effective model of empire was, of course, the most copious of all in engineering: that of Rome. Engineering was the Romans' ultimate art. Everywhere the empire reached, Romans and the elites they recruited as allies and confederates invested in infrastructure. They built roads, sewers and aqueducts. Amphitheatres, temples, city walls, public baths and monumental gates arose at public expense, alongside the temples that civic-minded patrons usually endowed. Rome exported the building patterns of roads, villas and cities to the provinces. There seems, then, to be a connection in this master case between infrastructure and empire, with mobility as a result and an expression of a compromise between politics and governance. Empires are not, save in a very general sense, like machines. But they have articulated parts that material infrastructure binds and politics lubricate to make possible human conversation (Gil 2014, 196).

Public Works in all cases appear to be at the same time a cause and a consequence of imperial expansion, in the most environmentally diverse conditions. Of course, politics was relevant to explain when and where a port, a fortress, a city or a trade route was established at the time, and why it endured or not. Policies in the same period appear to contain contradictory strategies: playing 'barbarians' off against one another; or attracting them into peaceful submission or cooperation; intimidating them into surrender; or forcing them into peace; or exterminating them. Common to all these options were efforts to enhance frontier security and build permanent bridges. No alliance is permanent and no collaboration can be secured for ever. But remarkable cases of empires - Roman, Russian, Ottoman, Chinese, Spanish, among others - all of them long lasting, are still in need of comparative explanation.

\section{Atlantic Expansion}

Although the dynamics of indigenous societies favoured the growth of the European and Spanish overseas empires in the Early Modern period, there had to be something to grow. To keep collaboration going, the newly arrived had to reward the welldisposed. Public works were the true image of this sense of collaboration in the long 
term, and the development of mixed-race societies and technologies one of the explanations of imperial durability. Indefinability may be a revelatory feature of empires of the Early Modern period. Most people probably assume that strength is another typical feature. It is tempting to suppose that empires were powerful in order to coerce subjected and victimized peoples into submission. The assumption may be valid for post-industrial empires that can draw on formidable resources for communicating and enforcing their rulers' wills (Osterhammel 2009, 572). Early Modern empires, however, had no such resources. They laid, at times, heavy hands on subjects they could reach easily. But they did not control their peripheries. The bigger they were, the weaker they were on their frontiers, and the more compromised became mobility. Distance was a real wall, not a tale of success. In remote parts of the Spanish monarchy, local authorities were effectively exempt from imperial control, because it took so long for the metropolis to communicate. Depending on weather conditions, it took between 59 and 153 days to complete a voyage by sea from Cadiz to Veracruz; writers of royal commands had to reckon on about six months from Madrid to Mexico City, perhaps ten months to Santiago de Chile and as much as a year to Manila. It was the tyranny of geography over culture.

The most impressive feature of the Spanish monarchy - its enormous reach - was also a source of weakness, for it spread tenuously along effectively indefensible frontiers and vulnerable routes, with resources thinly distributed. But it was unique in pertinent ways. It was, until well into the eighteenth century, the world's only great empire of land and sea. On a big scale, in the eighteenth century, maritime empires shifted their centres of gravity landward. For Spain, there was nothing new in landward strategy. The Spanish empire acquired its dual character, maritime and landward, when Cortés conquered Mexico in 1519-1521 or even, perhaps, when the appropriation of parts of the Isthmus of Panama began earlier in the same decade. The Spanish record in sustaining imperial growth in competition with rivals - increasingly, as time went on, more powerful than Spain and in command of greater resources - is impressive, especially in view of the problems of defending over-extended frontiers and maintaining communications with pre-industrial technology. Spain acquired the most productive parts of continental America - Mesoamerica, the Isthmus, most of the Andean world, and the Paraguay and Paraná valleys - in the first half of the sixteenth century. The acquisitions included - miraculously according to some early colonial reminiscences - two of the world's most dynamic and aggressive empires of the day, those of the Aztecs and the Incas (Elliott 2006, 16). For the rest of the century, rival powers managed only sporadic forays, largely confined to piratical exploits, flitting and stinging on the edge of the Spanish Main. This extraordinary tale of success occurred despite Spain's perceived decline. Yet none of these afflictions could stop the Spanish empire growing in the New World. Expansion resumed towards the end of the seventeenth century with the re-occupation of New Mexico and the submission of the last independent Maya kingdom in 1697. After 1580, persistence of empire was related to the importance of cities. Roads and bridges, networks, itineraries, oceanic and land roads, explain such durability. 


\section{Urban Frontier}

The city of the conquistadores was deeply rooted in the experience of Spanish imperial power. At the same time, according to law, it was a political city with people of European, Native and African extraction mixing very fast. After 1569, Juan de Ovando, visitador of the Council of the Indies, met with governors and officers to make a new code of laws. It was divided into seven parts, full of common sense, regulating urban planning based on the doctrines of the first-century BC Roman architect and engineer Vitruvius. Cities had to be placed in regions with a good and healthy climate, "with good and happy constellation, the clear and benign sky, the pure and smooth air, without excess of heat or cold, and having to choose, it is better if it is cold' (Lucena Giraldo 2006, 66). The sites chosen would be located not in coastal or high mountains, but in fertile places with wood, fresh water, roads, and 'without poisonous animals or air corruption'. The initial population of a new city had to be at least 30 Spanish neighbours, in addition to natives and black people, free or slaves, approximately 180 people in total. Each would possess a house and land, while the city would have its common lands - comunes - and a place for cattle, the ejido. In the city, once chosen, the place for the main square or plaza mayor, with sides confronting the cathedral, royal houses and parcels for important families or conquistadores beneméritos, or even native collaborators, the streets and sites for churches, hospitals, markets and convents, could be laid out.

The aim of building a city is to open an 'entrance to the land', to maintain a frontier and settle in the middle of complex indigenous territories; i.e. to maintain imperial mobility. From 1600 onwards, with the whole Hapsburg monarchy collapsing in Europe, a new era arrived for the Spanish American cities, that of creole power. The invention of a legend about the past and present of the Spanish American cities was a key element of this new creole identity. The Renaissance city of the conquistadores turned out to be a creole metropolis, organic by nature, a biblical Jerusalem, both in the centre and the periphery of the monarchy, expressed through the artistic languages of the Baroque. That 'creole Jerusalem' was visible in the signs of nature, as the signs of God, to its inhabitants. As a Baroque city, it was dominated by status and circumstance. Space and time were conformed like enjoyment, and forgiveness of faults and sins through celebrations, rituals and ephemera. It rose according to the gridiron plan, the space divided in lots whose hierarchy depended on the distance from the centre. Some were capitals of great magnitude, while others never rose above the status of provincial cities, regional capitals or small towns. The great creole metropolises were the capitals of the viceroyalties of New Spain, Mexico, and Peru, Lima.

As cities governed by a powerful cabildo, a city council as the expression of local power, politics were, above all, local politics taking advantage of the sale of offices by the crown from 1580 onwards. The arrival and exit of viceroys and governors, royal birthdays, the celebration of saints - especially the local ones, some of them American born and some mulattoes, such as San Martín de Porres in Lima - and fairs and markets, organized the time and space of the cities. The size of the streets 
and the perspective opened by the gridiron favoured the splendour of fiestas and processions. In the religious celebrations and civil commemorations each one could negotiate its status, asking for a change through the mercy of somebody powerful, even the king himself.

\section{Enlightened Cities}

Although it is not clear when the creole metropolis came to an end, the Bourbon reforms which began to be implemented in 1750 changed the nature of the Spanish American city. The public works shaping everywhere a sense of urban community, and legal flexibility coming from the Atlantic constitution, were substituted by new, Enlightened, modern ideas of politics and mobility. The need for reforms paved the way for a change in local narratives. The cause of public progress badly needed the end of the political autonomy. The changes in the American cities arrived elsewhere. Lima was furnished with an academy of Fine Arts, anatomical cabinet, hospital and nautical school, roads and bridges coming from the port. Buenos Aires, a city with roads collapsed by mud and cows, got new streets, adorned with a lighting system. Santiago de Chile had a new cathedral, customs offices and a town hall, while in Quito there was a new palace of government. In Caracas, the bridges of Charles III and the Trinidad were built, a theatre for comedies and a big avenue, like that of the Paseo del Prado in Madrid, constructed.

The Spanish American city of fallen houses and churches and streets full of mud and water belonged to the past. The arrangement of the urban space was linked to long-term visionary policies. Direct control of the territory was taken over by military engineers, and army and navy officers, no longer missionaries or local amateurs, who planned and implemented big infrastructures. Public works expressed not only how power and limits defined the Spanish Habsburg Empire of the 1600s as an empire of cities, but also how the Bourbon Empire of the 1700s eventually disappeared in the transition to modernity.

\section{Acknowledgements}

This text is part of a common research conducted with Felipe Fernández-Armesto, from Notre Dame University, USA, with the invaluable support of the Rafael del Pino Foundation, Spain. I acknowledge support of the publication fee by the CSIC Open Access Publication Support Initiative through its Unit of Information Resources for Research (URICI).

\section{References}

Elliott JH (2006) Empires of the Atlantic World. Britain and Spain in America, 1492-1830. New Haven: Yale University Press. 
Gil X (2014) City, communication and concord in Renaissance Spain and Spanish America. In Kitromilides PM (ed.), Athenian Legacies, European Debates on Citizenship. Firenze: Olschki, pp. 195-222.

Lucena Giraldo M (2006) A los cuatro vientos. Las ciudades en la América Hispánica. Madrid: Marcial Pons.

Osterhammel J (2009) A Global History of the Nineteenth Century. Princeton, NJ: Princeton University Press.

Paquette G, Lucena Giraldo M, Quintero Saravia GM and Regué-Sendrós O (2018) Introduction, new directions in the political history of the Spanish-Atlantic world, c. 1750-1850. Journal of Iberian and Latin American Studies 24(2), 175-182. DOI: 10.1080/14701847.2018.1492325

\section{About the Author}

Manuel Lucena-Giraldo is Research Scientist in the Spanish Council for Scientific Research, based in Madrid. He was Visiting Scholar at Harvard University, Lecturer BOSP in Stanford University and Visiting Professor at Tufts University (Boston), Javeriana University (Colombia), IVIC (Venezuela), Colegio de México, University of the Andes (Chile and Colombia) and St. Antony's College (Oxford). His publications include a number of books on travels, scientific expeditions, cities, images of nations, empires or globalization. 